\title{
Laser therapy in peri-implantitis treatment: literature review
}

\author{
Kyung-Joong Lee ${ }^{1}$, Jong-Ho Lee ${ }^{2}$, Kee-Yeon Kum³ ${ }^{3}$ Young-Jun Lim* \\ ${ }^{1}$ Department of Prosthodontics ${ }^{2}$ Department of Oral and Maxillofacial Surgery, ${ }^{3}$ Department of Conservative Dentistry and \\ Dental Research Institute, School of Dentistry, Seoul National University, Seoul, Republic of Korea
}

\begin{abstract}
Peri-implantitis is the most common reason for a late failure and can occur even after years of successful osseointegration. The role of microbial plaque accumulation in the development of peri-implantitis has been well documented. On the other hand, the ideal method of implant surface decontamination to re-establish the health of peri-implant tissue remains to be determined. Removal of bacterial deposits is essential in the treatment of peri-implant infections, and various therapeutic approaches have been described in the literature, including mechanical debridement, disinfection with chemotherapeutic agents, and laser therapy. Recently, there has been a plenitude of scientific data regarding the use of laser irradiation to achieve titanium surface decontamination. Thus, research is focusing on lasers' potential use in the treatment of peri-implantitis. The aim of this literature review is to analyze and evaluate the efficacy of laser therapy for the treatment of peri-implantitis. (J Dent Rehabil Appl Sci 2015;31(4):340-8)
\end{abstract}

Key words: dental implant; peri-implantitis; laser therapy; debridement

\section{서론}

기계식 절삭 장치는 과거 100 여 년간 치과 영역에서 널리 이용되어 왔다. 점진적 연구 개발을 통해 장치는 더 작아지고 절삭 효율은 증가해 왔다. 그러나 핸드피스 또 는 초음파 스케일러에서 발생하는 진동과 소음, 이로부 터 환자가 느끼게 되는 공포는 아직도 해결되지 못한 과 제로 남아있다. ${ }^{1}$ 레이저는 이러한 기계식 접촉 장치를 대 체하는 수단으로 주목을 받아왔다.

레이저는 기계식 절삭장치와는 달리 조직에 마멸, 지 혈 및 정화(detoxification) 효과가 복합적으로 작용한다. 또한 정확한 절개 및 주변 조직에 대한 최소한의 손상 발 생으로 인해 술 후 통증이 적고 회복이 빠른 장점이 있는

${ }^{*}$ Correspondence to: Young-Jun Lim

Professor, Department of Prosthodontics, School of Dentistry, Seoul National University, 101 Daehak-ro, Jongno-gu, Seoul, 03080, Republic of Korea Tel: +82-2-2072-3816, Fax: +82-2-2072-3860, E-mail: limdds@snu.ac.kr Received: June 16, 2015/Last Revision: September 10, 2015/Accepted: December 5,2015
것으로 알려졌다. 소음과 진동이 미비하여 환자의 심리 적 편안함을 증진시키는 효과도 있다. ${ }^{1}$

레이저가 치과 임상에 활용되었던 초기에는 연조직 을 자르거나 지혈을 시키는 등 주로 연조직 술식에 사용 되었으나 치주질환의 처치, 치수처치, 근첨부질환의 치 료와 치아우식증의 치료에 레이저의 사용은 불가능하 였다. 직경이 적은 광섬유의 개발로 레이저의 구강내 전달이 가능하게 되어 현재는 pulsed Nd:YAG, Argon, Holmium, diode, Er:YAG, Er:YSGG 및 $\mathrm{CO}_{2}$ 레이저가 치과임상에 광범위하게 사용되고 있다.

각종 레이저의 임상응용을 살펴보면 $\mathrm{Er}: \mathrm{YAG}$, Er:YSGG 레이저는 치아우식증 등의 경조직 처치에 주 로 사용하며, 부가적으로 연조직 처치에 사용되고 있으
Copyright@ 2015 The Korean Academy of Stomatognathic Function and Occlusion. (c) It is identical to Creative Commons Non-Commercial License. 
나 지혈효과가 떨어지는 단점을 가지고 있다. 연조직 술식을 위해 확실한 조직의 제거가 요구되는 경우에는 diode, $\mathrm{CO}_{2}$ 레이저가 사용되나 광범위한 열손상이 일어 날 가능성이 있으므로 주의하여 사용해야 한다.

최근에는 임플란트 영역의 레이저 사용에 대한 연구 가 활발하게 이루어지고 있다. 임플란트 영역에서 사용 가능한 이상적인 레이저는 주위조직에 열손상을 최소로 하고 혈관을 응고시켜 정확한 시술을 가능케 하며 임플 란트주위염 치료 시 육아조직을 정확히 제거할 수 있어 야 한다. 비록 치과 임플란트가 치아를 상실한 경우 취 할 수 있는 성공적인 치료 옵션이지만 실패 또한 발생한 다. $^{2}$ 임플란트주위염은 임플란트의 후기 실패의 원인으 로 가장 높은 비율을 차지한다. ${ }^{3,4}$ 임플란트주위염은 미 생물 감염에 의한 염증성 질환으로 임플란트를 지지하 는 골의 소실을 동반하며 임플란트 주위의 미생물의 침 착으로 인한 염증반응이 주요 병인으로 알려져 있다., 임플란트 표면에 형성된 세균막에 대한 숙주 반응은 초 기에 연조직에 대한 염증반응으로 나타나고 진행되며 적절히 처치되지 않을 경우 임플란트 주위골의 진행적 인 파괴를 가져온다. 여러 연구들을 통해 미생물 침착이 임플란트주위염에 미치는 영향이 보고된 바 있으며 세 균막의 제거는 임플란트주위염의 치료 시 필수조건이 된다. 그에 반해 오염된 임플란트 표면을 정화하여 임플 란트 주위 조직의 건강을 회복하는 이상적인 방법에 대 해서는 아직 명확한 기준이 확립되지 않았다.

임플란트 주위의 미생물 침착을 제거하는 방법으로 티타늄보다 단단하지 않은 플라스틱 큐렛 등을 사용하 는 물리적 제거(mechanical debridement)와 함께 보조적 인 화학적 방법으로 항생제의 국소 또는 전신투여가 시 행되고, chlorhexidine과 같은 국소 살균제에 의한 세정 등이 사용되어 왔다., 또한 오염된 임플란트 표면 정화 에 air-abrasive device가 사용되고 있다. 최근에, 여러 연 구들을 통해 티타늄 임플란트에 레이저를 사용하여 표 면을 살균, 정화 시키는 방법에 대한 실험이 많이 보고 되고 있으며, 임플란트주위염 치료에 있어서 레이저 조 사의 잠재적인 효과가 주목을 받고 있다. ${ }^{10-12}$

생체 외 연구에서 Er:YAG, $\mathrm{CO}_{2}$, diode 레이저 조사 시 티타늄 표면의 세균이 높은 비율로 제거된 결과가 보고 되었다. ${ }^{10}$ 또한 $\mathrm{CO}_{2}$, diode 레이저는 조사 시 티타 늄 표면의 변화를 야기하지 않는다는 결과도 보고 되었 다. ${ }^{11,12}$ 또한 적절한 조건으로 조사 시 Er:YAG 레이저 또한 티타늄 표면의 변화를 야기하지 않으면서 표면 미
생물의 제거에 효과적이라는 연구도 발표되었다. ${ }^{11,12}$

그럼에도 불구하고, 임상에서 임플란트주위염 치료에 레이저를 사용하는 것에 대해 아직 신중한 입장을 보이 고 있다. 레이저 장치에 대한 초기 비용 부담이 발생하 는 것은 차치하더라도 임플란트주위염의 치료에 있어서 레이저의 사용이 비교적 최근에야 도입된 방법이라 이 론적 근거가 부족하다고 판단하기 때문이라고 보인다. 또한 다양한 레이저 중 어떤 레이저가 임플란트주위염 치료에 효과적이며, 레이저 사용 시 조사 조건에 대한 기준이 임상가들에게 낯설기 때문이라고 생각된다.

본 논문에서는 임플란트주위염의 치료에 있어서 레이 저가 갖는 효과에 대한 최근 연구 결과를 살펴보고자 한 다.

\section{본론}

임플란트주위염을 치료하는 이상적인 프로토콜에 대 한 합의는 아직 없지만 플라스틱 큐렛 등을 이용해서 오 염된 조직을 제거하는 것이 추천되어 왔다. ${ }^{13}$ 그러나 이 러한 기계적 제거 방법만으로는 임플란트 표면으로부터 세균과 오염된 산물을 완전히 제거하기 어렵다. ${ }^{14}$ 기계 적 제거 외에 화학적 제제나 항생제 투여 등을 병행하는 보조적 치료 요법이 추천되기도 하지만 그 효과가 미비 하거나 항생제 내성 등의 부작용에 대한 우려가 있어 왔 다. ${ }^{15}$ 따라서 레이저를 이용해 오염물을 제거하고 임플 란트 표면을 정화하는 요법이 주목을 받고 있다.

임플란트주위염에 이환된 임플란트의 표면을 레이 저 조사를 통해 치료하기 위해서는 오염된 임플란트 표 면을 효과적으로 정화함과 동시에 임플란트 표면의 변 화를 일으키지 않아야 한다. Kreisler 등은 Nd:YAG, $\mathrm{Ho}: Y A G, \mathrm{Er}: \mathrm{YAG}, \mathrm{CO}_{2}$ 레이저를 티타늄 임플란트 표면에 조사하였을 때 표면 변화 양상 비교를 통해 $\mathrm{Nd}: Y A G$ 와 Ho:YAG는 레이저 출력에 상관없이 표면 변화를 유발하여 임플란트 주위염 치료에 적합하지 않 다고 하였다. ${ }^{16}$ Romanos 등 또한 Nd:YAG, diode 레이저 조사 시 임플란트 표면의 변화를 관찰한 결과 $\mathrm{Nd:YAG}$ 레이저는 출력에 상관없이 임플란트 표면 변화를 야기 하여 적합하지 않다고 하였다. ${ }^{17}$

따라서 치과 영역에 주로 사용되는 레이저 중 Er:YAG, $\mathrm{CO}_{2}$, diode 레이저 사용 시 임플란트주위염 치 료 효과 및 임플란트 표면, 임플란트 주위 조직에 미치 는 영향에 관한 연구를 살펴보고자 한다. 


\section{1. 임플란트주위염 치료에 $\mathrm{Er}: Y A G$ 레이저 적용}

치과 영역에서 주로 사용되는 Er:YAG 레이저의 파장 은 2.94 um로 수분에 대한 흡수도가 매우 높다. 일반적 으로 수분에 대한 흡수도가 높을수록 주변 조직의 불필 요한 손상이 적다.

임플란트주위염의 치료가 효과적으로 이뤄지기 위해 서는 오염된 임플란트 표면의 정화뿐만 아니라 임플란 트 주위에 형성되어 있는 육아조직의 제거가 동반되어 야 한다. 치과 영역에서 사용되는 레이저들 중 Er:YAG 는 임플란트 주위조직의 열손상을 유발하지 않으면서 육아조직 제거와 임플란트 표면 정화를 함께 이룰 수 있 는 특징을 가진다.

일부 연구에서 적절한 에너지 세팅으로 Er:YAG 레이 저를 조사하였을 때 티타늄 표면에 변화가 없었다. ${ }^{18,19}$ Matsuyama 등은 임플란트 표면에 조사조건을 달리하여 Er:YAG 레이저를 조사한 후 표면 변화, 온도 상승 여부 에 대해 실험한 결과 $50 \mathrm{~mJ} / \mathrm{pulse}$ 이하에서 임플란트 표 면의 형태학적 변화는 관찰되지 않았고 온도 상승도 최 소로 관찰되었다. ${ }^{18}$ 그러나 Er:YAG 레이저를 $100 \mathrm{~mJ} /$ pulse 이상의 높은 에너지로 조사하였을 때는 티타늄 표 면에 현저한 변화가 관찰되었으므로 주의가 필요하다. ${ }^{18}$ Schwarz 등은 $100 \mathrm{~mJ} / \mathrm{pulse}, 10 \mathrm{~Hz}$ 로 Er:YAG 레이저 를 조사하였을 때 임플란트 표면의 조골세포의 부착율 은 영향을 받지 않는다는 결과를 얻었다. ${ }^{19}$ 또한 Er:YAG 레이저는 임플란트 표면에 부착된 치태 및 치석의 제거 에 효과적이라는 연구도 있었으며, ${ }^{18,20}$ 일반적인 물리 적 정화 방법에 비해 높은 살균력을 보였다는 연구결과 도 있었다. ${ }^{20}$ Friedmann 등에 의하면 P. gingivalis에 오염 된 임플란트 표면에서 물리적 제거법을 시도한 후 임플 란트 표면에 조골세포의 부착이 나타나지 않은 반면에 Er:YAG 레이저를 처리한 경우 조골 세포의 부착이 증 가하였다고 하였다. ${ }^{21}$ Kreisler 등은 생체 내 실험에서 Er:YAG 레이저를 사용하였을 때 임플란트-골 계면에 온도 상승은 관찰되지 않았다고 하였다. ${ }^{22}$

최근에 이르러 생체 내에서 임플란트주위염의 비수술 적 접근에 Er:YAG 레이저를 이용한 연구가 있었다. ${ }^{23-25}$

Schwarz 등은 임플란트주위염의 비수술적 치료 시 실 험군으로 Er:YAG 레이저를 조사한 경우와 대조군으로 플라스틱 큐렛을 사용하여 물리적 제거를 한 후 $0.2 \%$ chlorhexidine을 적용한 방법을 비교하여 연구한 결과 를 보고하였다. ${ }^{23,24}$ 결과를 보면 치료 후 6개월 시점까지
는 두 그룹에서 치주낭 깊이와 결합조직 부착 소실에 유 의미한 감소가 나타났으나 이러한 감소가 12 개월까지 는 유지되지 못하였다고 하였고, 실험군과 대조군 사이 에 차이는 관찰되지 않는다고 하였다. 탐침 시 출혈의 감소는 두 그룹에서 유의미하게 나타났으며, 두 그룹 중 Er:YAG 레이저를 조사한 경우가 더 효과적이라고 하 였다. Schwarz 등은 또 다른 연구를 통해 임플란트주위 염을 비수술적 접근법으로 치료한 후 24개월에 조직병 리검사를 시행한 결과 여전히 결합조직 간질에 만성 염 증세포가 침윤되어 있다는 결과를 얻었고 따라서 비수 술적 접근으로 임플란트주위염을 완전히 치료할 수 없 다고 하였다. ${ }^{25}$ Renvert 등은 임플란트주위염의 비수술 적 치료 시 실험군으로 Er:YAG 레이저를 조사한 경우 와 대조군으로 air-abrasive device를 사용한 방법을 비교 하여 연구한 결과를 보고하였는데, 치료 6개월 시점에서 두 그룹에서 탐침 시 출혈의 유의미한 감소는 관찰되었 으나 치주낭 깊이의 유의미한 감소는 관찰되지 않았다 고 하였다. ${ }^{26}$

임플란트주위염의 수술적 접근에 Er:YAG 레이저를 이용한 연구도 있었다. ${ }^{27-29}$

Schwarz 등은 동물실험을 통해 판막 수술 중 임플란 트 표면에 Er:YAG 레이저를 적용하였을 때 대부분의 임상지표에서 효과가 있음을 확인하였고 기존의 물리 적 방법에 비해 재골유착(re-osseointegration)을 촉진 한다고 하였다. ${ }^{27}$ 또한 오염된 임플란트에 실험군으로 $\mathrm{Er}: Y A G$ 레이저를 조사한 경우와 대조군으로 플라스 틱 큐렛을 사용하여 물리적 제거를 한 후 멸균 식염수를 적용한 방법을 비교하여 연구한 결과를 보고하였다. 치 료 후 12 개월까지는 두 방법 모두 치주낭 깊이의 유의 미한 감소가 관찰되었으나 24개월 후에는 대조군에서 만 치주낭 깊이의 유의미한 감소가 유지되었다. 결합조 직 부착 소실와 탐침 시 출혈은 두 그룹에서 치료 후 12 개월 시점까지 유의미한 감소가 관찰되었고 그 이후에 는 감소 정도가 유의미하지 않았다. ${ }^{28}$ Takasaki 등은 개 에서 임플란트주위염 치료에 Er:YAG 레이저를 조사 한 연구를 통해 육아조직 제거와 임플란트 표면 정화에 Er:YAG 레이저가 물리적 정화법에 비해 좀더 효과적 이고 안전하다고 하였다. ${ }^{29}$ 또한 치료 24주 후에 조직시 편 관찰 결과 Er:YAG 레이저를 적용한 경우 물리적 방 법에 비해 새로 형성된 골이 더 임플란트 표면 상방까지 위치해있음을 통해 Er:YAG 레이저 조사시 새 골 형성 이 저해되지 않으며 레이저 조사된 임플란트 표면의 생 
체적합성은 증가한다고 하였다.

\section{2. 임플란트주위염 치료에 $\mathrm{CO}_{2}$ 레이저 적용}

치과 영역에서 주로 사용되는 $\mathrm{CO}_{2}$ 레이저는 $10.6 \mathrm{um}$ 의 파장을 가지며, 진동파 혹은 연속파 모드로 사용 가 능하다.

$\mathrm{CO}_{2}$ 레이저를 임플란트 표면에 조사하였을 때, 표 면의 형태학적 변화가 관찰되지 않았다는 연구가 있었 다. ${ }^{11,12}$ 또한 $\mathrm{CO}_{2}$ 레이저 사용 시 티타늄 표면의 조골세 포의 부착에 영향을 미치지 않는 것으로 나타나서 임플 란트 표면의 정화에 사용되고 있다. ${ }^{30,31} \mathrm{CO}_{2}$ 레이저는 안전하며 오염된 임플란트 표면에 조사 시 골 재생을 촉 진시킨다는 결과도 보고되었다. ${ }^{32}$

$\mathrm{CO}_{2}$ 레이저를 임플란트에 적용할 때, 임플란트-골 계 면의 온도상승 정도를 확인하기 위한 여러 연구가 있었 다. Ganz은 레이저 출력과 시간을 달리하여 임플란트에 조사하였을 때 온도변화에 대해 조사한 결과 연속파 모 드로 $2,4 \mathrm{~W}$ 의 레이저를 4 초까지 조사하였을 때 온도상 승이 $7{ }^{\circ} \mathrm{F}$ 를 넘지 않는 정도로 작다고 하였다..$^{33}$ 그러나 높은 출력으로 $\mathrm{CO}_{2}$ 레이저를 적용하였을 때 티타늄 임 플란트 표면의 온도가 유의미하게 상승할 위험성이 있 다는 연구결과가 있어 주의가 필요하다. ${ }^{34,35,36}$ Kreisler 등 은 임플란트 표면에 레이저 조사 조건을 달리 하여 임플 란트-골 계면의 온도 상승을 관찰한 결과 연속파 모드로 $1.0 \mathrm{~W}$ 로 56 초, $1.5 \mathrm{~W}$ 로 35 초, $2.5 \mathrm{~W}$ 로 15 초 조사 시 임 계온도인 $47^{\circ} \mathrm{C}$ 를 넘어섰다고 하였고, ${ }^{34}$ Mouhyi 등은 진 동파 모드로 output power, pulse width, pulse repetition rate, irradiation period를 달리하여 임플란트 표면에 조 사한 후 온도변화를 관찰하였는데 $8 \mathrm{~W} / 10 \mathrm{~ms} / 20 \mathrm{hz}$ 로 5 초동안 조사하였을 때 온도상승이 $3^{\circ} \mathrm{C}$ 미만으로 나 타나 온도상승에 대한 위험을 줄일 수 있다고 하였다. ${ }^{35}$ Oyster 등은 임플란트 표면에 출력과 조사시간을 달리 하여 임플란트-골 계면의 상부와 하부에서 온도 변화 를 살펴보는 실험을 하였는데 조사 조건에 따라 임플란 트-골 계면의 상부에서는 $1.2-11.7^{\circ} \mathrm{C}$, 하부에서는 0.0 $5.0^{\circ} \mathrm{C}$ 의 온도 상승이 관찰됨을 통해 레이저의 조사 조건 에 따라 온도 상승 정도가 달라지므로 주의해야 한다고 하였다. ${ }^{37}$

사람을 대상으로 레이저를 이용한 표면 정화와 골이 식을 통해 임플란트주위염을 치료한 연구들이 있다. Deppe 등은 오염된 임플란트 표면에 $\mathrm{CO}_{2}$ 레이저를 조
사한 그룹과 일반적인 방법으로 치료한 그룹으로 나누 어 표면 정화 및 골이식 후 결과를 비교하였다. ${ }^{38}$ 치료 4 개월 후에 레이저 치료 후 골이식한 그룹에서 임플란트골 결합 및 임상 지표들의 향상이 관찰되었으나 결과가 장기간 유지되진 않았다. 따라서 저자는 임플란트주위 염 치료에 있어서 단기간 동안에는 레이저를 사용한 그 룹에서 더 좋은 결과를 보이나 시간이 지난 후 두 그룹 간에 차이는 관찰되지 않는다고 하였다. 또한 치료 후 4 개의 임플란트에서 만성염증으로 인해 임플란트의 실패 로 이어졌다고 보고하였다. Romanos와 Nentwig는 임 플란트주위염 치료에 있어서 레이저 조사와 골이식을 동반한 치료 시 치주낭 깊이, 탐침 시 출혈, 결합조직 부 착 소실이 감소된 것을 통해 임플란트주위염 치료 시 레 이저 치료와 골이식을 동반한 치료는 효과적이라고 하 였다. ${ }^{39}$

\section{3. 임플란트주위염 치료에 diode 레이저 적용}

가장 일반적으로 사용되는 diode 레이저는 galliumaluminum-arsenide (GaAlAs) 레이저 $(810 \mathrm{~nm})$ 와 indiumgallium-arsenide-phosphide (InGaAsP) 레이저(980 nm) 이며 diode 레이저는 연속파 혹은 진동파 모드로 사용가 능하다..$^{40}$

Diode 레이저는 물에 흡수가 적게 되므로 조직으로의 침투율이 높아 조사되는 부분과 그 주변에 온도 상승을 유발할 위험이 있다. Kreisler 등에 의하면 GaAlAs 레이 저를 조건을 달리하여 임플란트 표면에 조사한 결과 1.0 $\mathrm{W}$ 로 30.5초, $1.5 \mathrm{~W}$ 로 18.0초, $2.0 \mathrm{~W}$ 로 12.5초, $2.5 \mathrm{~W}$ 로 9초, 조사 시 임계온도인 $47^{\circ} \mathrm{C}$ 를 넘어섰다고 하였고, 이 결과를 통해 임플란트주위염 치료 시 GaAlAs 레이저의 조사 시간과 출력을 제한하여야 임플란트 주위 골의 온 도 상승에 따른 손상을 막을 수 있다고 하였다. ${ }^{41}$

Diode 레이저 조사 시 임플란트 표면 손상 가능성에 대해서 Kreisler 등은 GaAIAs 레이저를 사용하여 $7 \mathrm{~W}$ $\left(50 \mathrm{~Hz} ; 26.6 \mathrm{~J} \mathrm{~cm}^{2}\right)$ 의 출력으로까지 조사하였을 때 임플 란트 표면 손상이 관찰되지 않았으며, ${ }^{16}$ Castro 등의 연 구에서도 유사한 결과를 보였다. ${ }^{42}$

일부 연구에서는 diode 레이저를 이용한 치료가 chlorhexidine을 동반한 물리적 정화법에 비해 임플란 트주위염에 덜 효과적이라고 나타났다. ${ }^{43}$ 또한 Schar 등 은 $660 \mathrm{~nm}, 100 \mathrm{~mW}$ 의 diode 레이저와 phenothiazine chloride dye를 조합하여 임플란트주위염을 비수술적 방 
법으로 치료하였다. ${ }^{44}$ Minocycline을 임플란트 주위 열구 에 적용한 대조군과 비교하였을 때, 임상지표에서 두 그 룹간의 유의미한 차이는 없었으며, 두 방법 모두 임플란 트주위염의 완전한 치료가 이루어지지 않았다고 하였다.

\section{결론}

레이저를 이용한 임플란트 표면 오염 정화 방식은 큐 렛, 초음파 스케일러와 같은 기계적 정화 방식을 대체할 유력한 후보임이 분명하다. 상용화된 레이저 장치가 임 플란트주위염 치료를 위해 사용되고 있음에도 불구하 고, 아직 그 임상적 효능에 대해서는 의견이 분분하다. 최근에 발표된 문헌 고찰 연구를 통해 레이저의 치료 효 과에 대해 살펴본 결과, 신뢰할만한 무작위 비교 연구의 수가 극히 미비함을 알 수 있었다.

이전의 여러 연구에 의해서 밝혀졌듯이 임플란트주위 염의 치료에 있어서는 비수술적 방법은 제한된 효과를 보이며 임상적으로 적절한 치료 결과를 얻기 위해서는 수술적 접근이 필요할 것으로 보인다. 수술적 접근을 통 한 레이저의 사용은 비수술적 접근 시와 비교해봤을 때 치주낭 깊이, 결합조직 부착 소실 등의 임상지표의 감소 가 적어도 2 배 정도 차이가 났다 그러나 몇몇 연구에서
레이저 치료 후 치료 효과가 장기간 유지되지 않는다고 하였으며, ${ }^{28,38} \mathrm{Er}: \mathrm{YAG}$ 레이저의 효과에 대한 메타 분석 결과 Er:YAG 레이저 적용 후 치주낭 깊이와 결합조직 부착 소실 감소가 통계적으로 유의미하지 않은 것으로 나타났다(Fig. 1, 2). ${ }^{45}$ 또한 임플란트주위염 치료에 물리 적 정화 방법에 비해 레이저 적용법이 더 효과적인지에 대해서는 의견이 분분한 상황이다. 레이저를 이용한 임 플란트주위염의 치료 시 이와 같은 한계를 극복하기 위 해서는 향후 더 많은 연구가 필요할 것으로 보인다.

일반적으로 임플란트주위염 치료에 레이저를 적용한 대부분의 연구에서 레이저 적용 모드, 레이저 출력, 임플 란트 표면에 대한 레이저 적용시간, 광섬유의 직경, 진 동의 주기 등에 대해 확실하게 명시하지 않고 있다. 같 은 파장의 레이저라도 적용하는 조건에 따라 임플란트 표면의 손상이나 온도 상승 등의 부작용을 일으킬 가능 성이 있기 때문에 이러한 정보들이 중요하다. 따라서 임 플란트주위염의 치료에 있어서 일반적인 방법과 대비하 여 레이저 치료의 효과를 알아보는 연구도 중요하지만 레이저 적용 시 부작용을 줄이면서 효과를 극대화시킬 수 있는 적절한 조건을 제시하는 연구 또한 앞으로 더욱 필요하다고 생각된다.

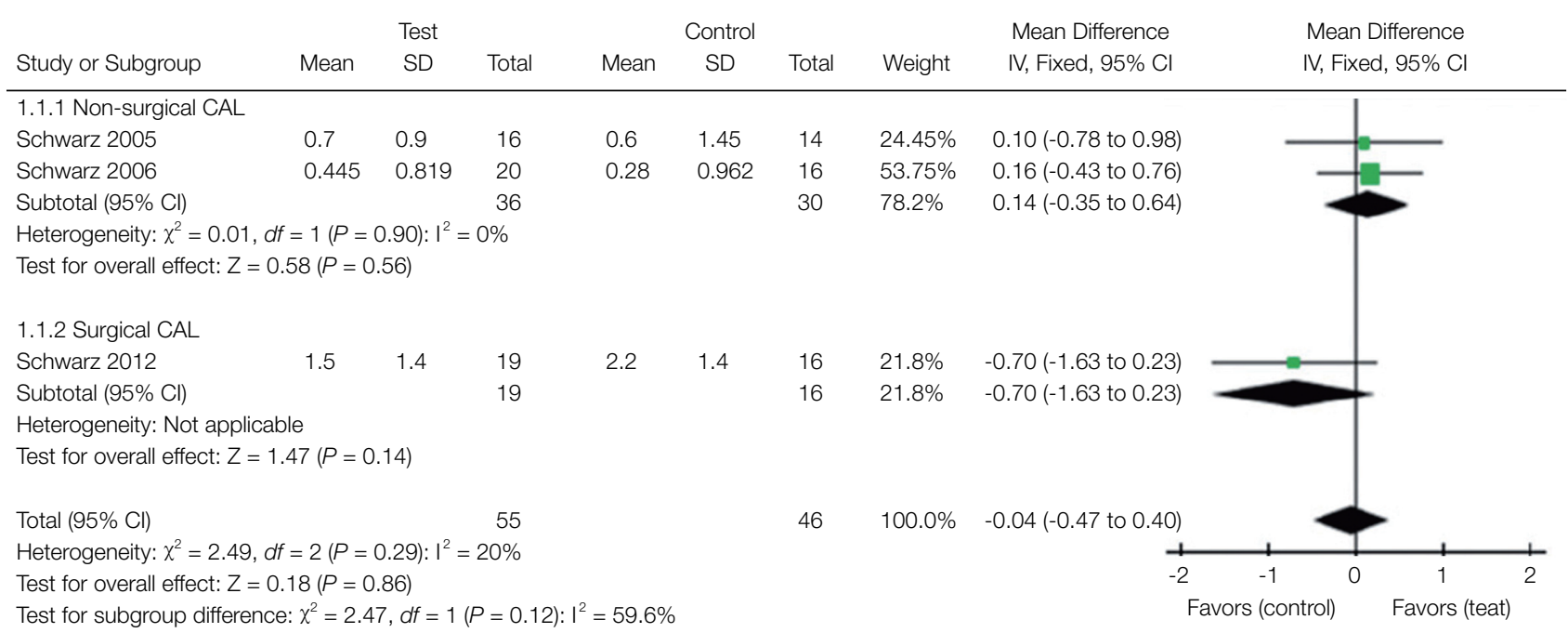

Fig. 1. Forest plot for selected studies reporting CAL changes after 6 months of treatment. Weighted mean differences were estimated by a fixed-effects model. Mean difference $>0$ indicates better treatment effect in the laser group than the control group.

$\mathrm{CAL}$, clinical attachment level; SD, standard deviation; $\mathrm{Cl}$, confidence Interval; df, degrees of freedom. 


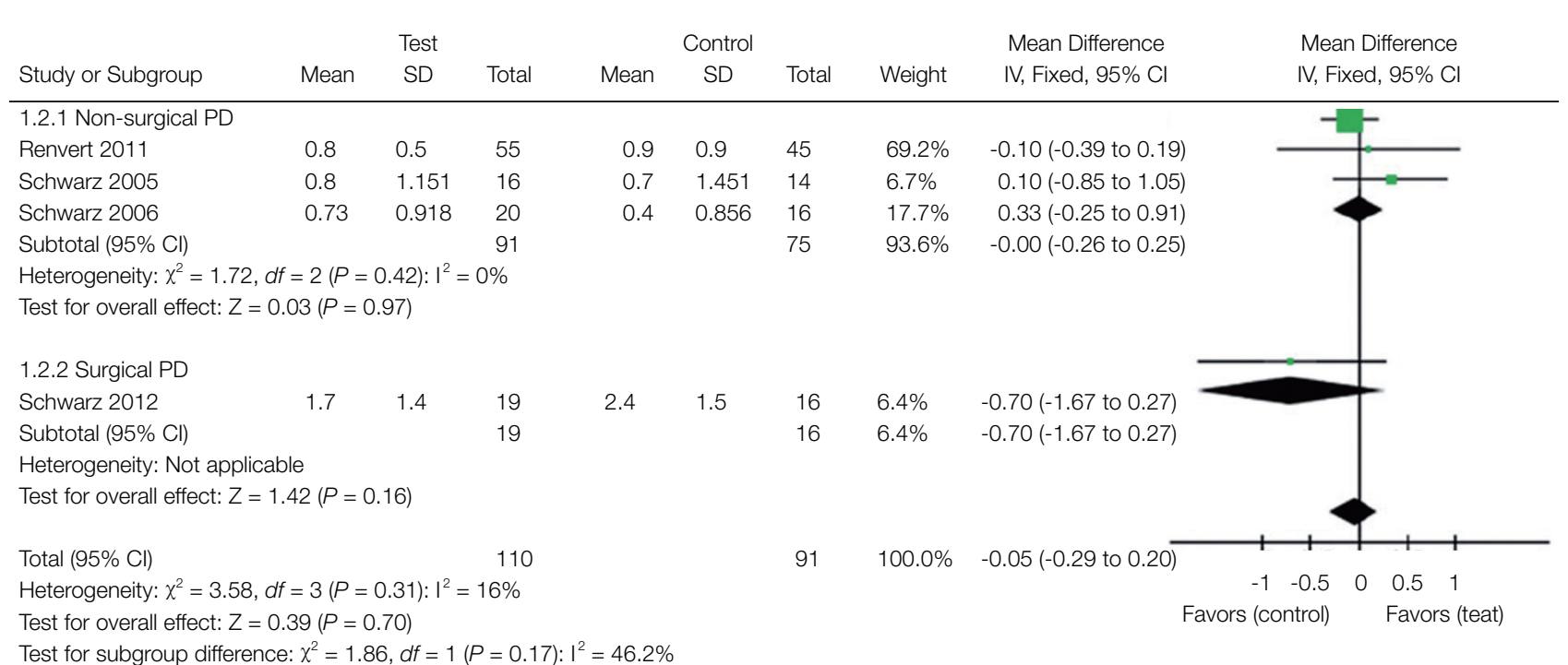

Fig. 2. Forest plot for selected studies reporting PD changes after 6 months of treatment. Weighted mean differences were estimated by a fixed-effects model. Mean difference $>0$ indicates better treatment effect in the laser group than the control group.

$\mathrm{PD}$, probing depth; SD, standard deviation; $\mathrm{Cl}$, confidence Interval; df, degrees of freedom.

\section{Acknowledgments}

본 연구는 산업통상자원부의 재원으로 신성장동력 장비경쟁력 강화사업의 지원에 의하여 이루어진 것임 (10047615).

\section{ORCID}

Kyung-Joong Lee http://orcid.org/Lee0000-0003-32550130

Jong-Ho Lee http://orcid.org/0000-0002-8843-545X

Kee-Yeon Kum http://orcid.org/0000-0002-3032-3498

Young-Jun Lim http://orcid.org/0000-0003-2504-9671

\section{References}

1. Ishikawa I, Aoki A, Takasaki AA, Mizutani K, Sasaki KM, Izumi Y. Application of lasers in periodontics: true innovation or myth? Periodontol 2000 2009;50:90-126.

2. Adell R, Lekholm U, Rockler B, Brånemark PI. A 15-year study of osseointegrated implants in the treatment of the edentulous jaw. Int J Oral Surg
1981;10:387-416.

3. Berglundh T, Persson L, Klinge B. A systematic review of the incidence of biological and technical complications in implant dentistry reported in prospective longitudinal studies of at least 5 years. J Clin Periodontol 2002;29 Suppl 3:197-212.

4. Atieh MA, Alsabeeha NH, Faggion CM Jr., Duncan WJ. The frequency of peri-implant diseases: a systematic review and meta-analysis. J Periodontol 2013;84:1586-98.

5. Lindhe J, Meyle J; Group D of European Workshop on Periodontology. Peri-implant diseases: consensus report of the sixth European workshop on Periodontology. J Clin Periodontol 2008;35 Suppl 8:282-5.

6. Froum SJ, Rosen PS. A proposed classification for peri-implantitis. Int J Periodontics Restorative Dent 2012;32:533-40.

7. Esposito M, Grusovin MG, Kakisis I, Coulthard P, Worthington HV. Interventions for replacing missing teeth: treatment of perimplantitis. Cochrane Database Syst Rev 2008;16:CD004970.

8. Kotsovilis S, Karoussis IK, Trianti M, Fourmousis I. Therapy of peri-implantitis: a systematic review. J 
Clin Periodontol 2008;35:621-9.

9. Ntrouka VI, Slot DE, Louropoulou A, Van der Weijden F. The effect of chemotherapeutic agents on contaminated titanium surfaces: a systematic review. Clin Oral Implants Res 2011;22:681-90.

10. Tosun E, Tasar F, Strauss R, Kivanc DG, Ungor C. Comparative evaluation of antimicrobial effects of Er:YAG, diode, and $\mathrm{CO}_{2}$ lasers on titanium discs: an experimental study. J Oral Maxillofac Surg 2012;70:1064-9.

11. Stubinger S, Etter C, Miskiewicz M, Homann F, Saldamli B, Wieland M, Sader R. Surface alterations of polished and sandblasted and acidetched titanium implants after Er:YAG, carbon dioxide, and diode laser irradiation. Int J Oral Maxillofac Implants 2010;25:104-11.

12. Park JH, Heo SJ, Koak JY, Kim SK, Han CH, Lee JH. Effects of laser irradiation on machined and anodized titanium disks. Int J Oral Maxillofac Implants 2012;27:265-72.

13. Roos-Jansåker AM, Renvert S, Egelberg J. Treatment of peri-implant infections: a literature review. J Clin Periodontol 2003:30:467-85.

14. Schwarz F, Sculean A, Romanos G, Herten M, Horn N, Scherbaum W, Becker J. Influence of different treatment approaches on the removal of early plaque biofilms and the viability of SAOS2 osteoblasts grown on titanium implants. Clin Oral Investig 2005:9:111-7.

15. Schou S, Holmstrup P, Jørgensen T, Skovgaard LT, Stoltze K, Hjørting-Hansen E, Wenzel A. Implant surface preparation in the surgical treatment of experimental peri-implantitis with autogenous bone graft and ePTFE membrane in cynomolgus monkeys. Clin Oral Implants Res 2003;14:412-22.

16. Kreisler M, Götz H, Duschner H. Effect of Nd:YAG, Ho:YAG, Er:YAG, $\mathrm{CO}_{2}$, and GaAIAs laser irradiation on surface properties of endosseous dental implants. Int J Oral Maxillofac Implants 2002;17:202-11.

17. Romanos GE, Everts H, Nentwig GH. Effects of diode and $\mathrm{Nd}$ :YAG laser irradiation on titanium discs: a scanning electron microscope examination. J Periodontol 2000;71:810-5.

18. Matsuyama T, Aoki A, Oda S, Yoneyama T, Ishika- wa I. Effects of the Er:YAG laser irradiation on titanium implant materials and contaminated implant abutment surfaces. J Clin Laser Med Surg 2003;21: 7-17.

19. Schwarz F, Rothamel D, Sculean A, Georg T, Scherbaum W, Becker J. Effects of an Er:YAG laser and the vector ultrasonic system on the biocompatibility of titanium implants in cultures of human osteoblast-like cells. Clin Oral Implants Res 2003; 14:784-92.

20. Schwarz F, Sculean A, Romanos G, Herten M, Horn N, Scherbaum W, Becker J. Influence of different treatment approaches on the removal of early plaque biofilms and the viability of SAOS2 osteoblasts grown on titanium implants. Clin Oral Investig 2005;9:111-7.

21. Friedmann A, Antic L, Bernimoulin JP, Purucker P. In vitro attachment of osteoblasts on contaminated rough titanium surfaces treated by Er:YAG laser. J Biomed Mater Res A 2006;79:53-60.

22. Kreisler M, Al Haj H, d'Hoedt B. Temperature changes at the implant-bone interface during simulated surface decontamination with an Er:YAG laser. Int J Prosthodont 2002;15:582-7.

23. Schwarz F, Bieling K, Bonsmann M, Latz T, Becker J. Nonsurgical treatment of moderate and advanced peri-implantitis lesions: a controlled clinical study. Clin Oral Investig 2006;10:279-88.

24. Schwarz F, Sculean A, Rothamel D, Schwenzer K, Georg T, Becker J. Clinical evaluation of an Er:YAG laser for nonsurgical treatment of periimplantitis: a pilot study. Clin Oral Implants Res 2005;16:44-52.

25. Schwarz F, Bieling K, Nuesry E, Sculean A, Becker J. Clinical and histological healing pattern of periimplantitis lesions following non-surgical treatment with an Er:YAG laser. Lasers Surg Med 2006;38: 663-71.

26. Renvert S, Lindahl C, Roos Jansåker AM, Persson GR. Treatment of peri-implantitis using an Er:YAG laser or an air-abrasive device: a randomized clinical trial. J Clin Periodontol 2011;38:65-73.

27. Schwarz F, Jepsen S, Herten M, Sager M, Rothamel $\mathrm{D}$, Becker J. Influence of different treatment approaches on non-submerged and submerged heal- 
ing of ligature induced peri-implantitis lesions: an experimental study in dogs. J Clin Periodontol 2006;33:584-95.

28. Schwarz F, John G, Mainusch S, Sahm N, Becker J. Combined surgical therapy of peri-implantitis evaluating two methods of surface debridement and decontamination. A two-year clinical follow up report. J Clin Periodontol 2012;39:789-97.

29. Takasaki AA, Aoki A, Mizutani K, Kikuchi S, Oda S, Ishikawa I. Er:YAG laser therapy for peri-implant infection: a histological study. Lasers Med Sci 2007; 22:143-57.

30. Crespi R, Romanos GE, Cassinelli C, Gherlone E. Effects of Er:YAG laser and ultrasonic treatment on fibroblast attachment to root surfaces: an in vitro study. J Periodontol 2006;77:1217-22.

31. Kato T, Kusakari H, Hoshino E. Bactericidal efficacy of carbon dioxide laser against bacteria-contaminated titanium implant and subsequent cellular adhesion to irradiated area. Lasers Surg Med 1998; 23:299-309.

32. Stubinger S, Henke J, Donath K, Deppe H. Bone regeneration after peri-implant care with the $\mathrm{CO}_{2}$ laser: a fluorescence microscopy study. Int J Oral Maxillofac Implants 2005;20:203-10.

33. Ganz CH. Evaluation of the safety of the carbon dioxide laser used in conjunction with root form implants: a pilot study. J Prosthet Dent 1997;71:2730.

34. Kreisler M, Al Haj H, Götz H, Duschner H, d' Hoedt B. Effect of simulated $\mathrm{CO}_{2}$ and GaAlAs laser surface decontamination on temperature changes in Ti-plasma sprayed dental implants. Lasers Surg Med 2002;30:233-9.

35. Mouhyi J, Sennerby L, Nammour S, Guillaume P, Van Reck J. Temperature increases during surface decontamination of titanium implants using $\mathrm{CO}_{2}$ laser. Clin Oral Implants Res 1999;10:54-61.

36. Kato T, Kusakari H, Hoshino E. Bactericidal efficacy of carbon dioxide laser against bacteria-contaminated titanium implant and subsequent cellular adhesion to irradiated area. Lasers Surg Med 1998; 23:299-309.

37. Oyster DK, Parker WB, Gher ME. $\mathrm{CO}_{2}$ lasers and temperature changes of titanium implants. J Periodontol 1995;66:1017-24.

38. Deppe H, Horch HH, Neff A. Conventional versus $\mathrm{CO}_{2}$ laser-assisted treatment of peri-implant defects with the concomitant use of pure-phase beta-tricalcium phosphate: a 5 -year clinical report. Int J Oral Maxillofac Implants 2007;22:79-86.

39. Romanos GE, Nentwig GH. Regenerative therapy of deep periimplant infrabony defects after $\mathrm{CO}_{2}$ laser implant surface decontamination. Int J Periodontics Restorative Dent 2008;28:245-55.

40. Schwarz F, Aoki A, Sculean A, Becker J. The impact of laser application on periodontal and peri-implant wound healing. Periodontol 2000 2009;51:79-108.

41. Kreisler M, Al Haj H, D’ Hoedt B. Temperature changes induced by $809-\mathrm{nm}$ GaAlAs laser at the implant-bone interface during simulated surface decontamination. Clin Oral Implants Res 2003;14:916.

42. Castro GL, Gallas M, Nũñez IR, Borrajo JL, Alvarez JC, Varela LG. Scanning electron microscopic analysis of diode laser-treated titanium implant surfaces. Photomed Laser Surg 2007;25:124-8.

43. Kreisler M, Kohnen W, Marinello C, Schoof J, Langnau E, Jansen B, d' Hoedt B. Antimicrobial efficacy of semiconductor laser irradiation on implant surfaces. Int J Oral Maxillofac Implants 2003; 18:706-11.

44. Schar D, Ramseier CA, Eick S, Arweiler NB, Sculean A, Salvi GE. Anti-infective therapy of periimplantitis with adjunctive local drug delivery or photodynamic therapy: six-month outcomes of a prospective randomized clinical trial. Clin Oral Implants Res 2013;24:104-10.

45. Kotsakis GA, Konstantinidis I, Karoussis IK, Ma X, $\mathrm{Chu} \mathrm{H}$. Systematic review and meta-analysis of the effect of various laser wavelengths in the treatment of peri-implantitis. J Periodontol 2014;85:1203-13. 


\section{임플란트주위염 처치에서 레이저의 이용: 문헌고찰}

\section{이경중 ${ }^{1}$, 이종호 ${ }^{2}$, 금기연 ${ }^{3}$, 임영준 $^{*}$}

서울대학교 치의학대학원 및 구강과학연구소 ${ }^{1}$ 치과보철학교실, ${ }^{2}$ 구강악안면외과학교실, ${ }^{3}$ 치과보존학교실

임플란트주위염(peri-implantitis)은 기능중인 골유착 임플란트 주위의 조직에서 생기는 사이트 별 감염성 질환이며 임 플란트 후기 실패(late failure)의 원인으로 가장 높은 비율을 차지한다. 여러 연구들을 통해 미생물 침착이 임플란트주 위염에 미치는 영향이 보고된 바 있으며 세균막의 제거는 임플란트주위염의 치료 시 필수조건이 된다. 최근에 여러 연 구들을 통해 티타늄 임플란트에 레이저를 사용하여 표면을 살균, 정화 시키는 방법에 대한 실험이 많이 보고되고 있다. 본 논문에서는 임플란트주위염 처치에 있어 레이저가 갖는 효능에 대한 최근 연구 결과들을 문헌고찰을 통해 되짚어보 고자 한다.

(구강회복응용과학지 2015;31 (4):340-8)

주요어: 치과임플란트; 임플란트주위염; 레이저치료; 세정 